\title{
Osmolar Regulation of Endothelin Signaling in Rat Renal Medullary Interstitial Cells
}

\author{
Melchiore A. Vernace, * Peter F. Mento, ${ }^{\text {M Mary E. Maita, }{ }^{*} \text { Elizabeth P. Girardi, * Ming-der Y. Chang, }{ }^{\text {} ~ E d w a r d ~ P . ~ N o r d, ~}}$ \\ and Barry M. Wilkes* \\ ${ }^{*}$ Divisions of Nephrology/Hypertension and ${ }^{\ddagger}$ Molecular Medicine, Department of Medicine, North Shore University Hospital and the \\ Department of Medicine, Cornell University Medical College, Manhasset, New York 11030; and ${ }^{8}$ Division of Nephrology, Department of \\ Medicine, University Hospital, School of Medicine, State University of New York at Stony Brook, Stony Brook, New York 11794
}

\begin{abstract}
We tested the hypothesis that endothelin (ET) responsiveness in the renal medulla is modulated by ambient osmolarity. Cultured renal medullary interstitial cells (RMICs) were incubated from 3 to $24 \mathrm{~h}$ in isosmolar culture medium ( $300 \mathrm{mOsm} / \mathrm{kg} \mathrm{H}_{2} \mathrm{O}$ ) or media rendered hyperosmolar (600 $\mathrm{mOsm} / \mathrm{kg} \mathrm{H}_{2} \mathrm{O}$ ) by the addition of urea. Under hyperosmolar conditions, the peak of ET-evoked $\mathrm{Ca}^{2+}$ transient was blunted by $45-58 \%(P<0.02)$ and $P E_{2}$ accumulation decreased from 16- to 2 -fold above basal values $(P<0.001)$. To explore whether hyperosmolar conditions blunt intracellular signaling via modulation of receptor number or expression, kinetics of ET binding and Northern blot analysis of ET $_{A}$ receptor mRNA was performed. Under hyperosmolar conditions, $\mathbf{E T}_{\mathrm{A}}$ receptor density was reduced by $\mathbf{8 4 \%}$ versus isosmolar conditions $(238 \pm 12$ vs. $1450 \pm 184 \mathrm{fmol} /$ mg) $(P<0.01)$. In contrast to the ligand binding studies, ET $_{A}$ receptor mRNA was increased by $58 \%(P<0.05)$ in cells grown under hyperosmolar versus isosmolar media. These observations indicate that in the hyperosmolar setting, ET-evoked intracellular signaling is blunted in RMICs due to ET receptor downregulation. Since ET $_{A}$ receptor mRNA is increased under hyperosmolar conditions, we conclude that ET receptor downregulation is the consequence of either decreased translation of message, increased degradation of receptor peptide, or increased internalization of specific receptor sites. (J. Clin. Invest. 1995. 96:183-191.) Key words: receptor $\bullet$ hormone signaling • renal medulla • hyperosmolarity $\bullet$ cell regulation
\end{abstract}

\section{Introduction}

Endothelin-1 (ET) ${ }^{1}$ is a 21 -amino acid peptide with diverse actions. In the kidney the major sites of production are the

Address correspondence to Barry M. Wilkes, Division of Nephrology, Department of Medicine, North Shore University Hospital, 300 Community Dr., Manhasset, NY 11030. Phone: 516-562-4384; FAX: 516-5621599.

Received for publication 7 October 1994 and accepted in revised form 23 March 1995.

1. Abbreviations used in this paper: $\mathrm{ET}$, endothelin-1; $\mathrm{PGE}_{2}$, prostaglandin $\mathrm{E}_{2}$; PKC, protein kinase C; RMIC, renal medullary interstitial cell.

J. Clin. Invest.

(c) The American Society for Clinical Investigation, Inc. 0021-9738/95/07/0183/09 \$2.00

Volume 96, July 1995, 183-191 different elements within the glomerulus and inner medullary collecting duct cells $(1-3)$. ET has been shown to act on blood vessels, glomeruli, inner medullary collecting duct epithelium, and medullary interstitial cells. Although the most widely appreciated physiologic renal effect of ET is its potent and prolonged vasoconstrictor action, the peptide also has an important role in modulating distal nephron function (4-6). Nonconstrictor doses of ET have been shown to increase salt and water excretion in rabbits (5) and increase water excretion in rats (6). Indeed, ET has been shown to have a direct effect on modulating sodium transport $(7,8)$ and vasopressin-stimulated water permeability (9)

The renal medulla provides a unique environment where ambient osmolarity varies with the state of the concentrating mechanism. During antidiuresis, renal medullary osmolarity increases from 300 to $>1200 \mathrm{mOsm} / \mathrm{kg} \mathrm{H}_{2} \mathrm{O}$ primarily due to increases in urea and sodium concentration (10). Recently, increased osmolarity has been shown to reduce ET production in cultured renal epithelial cells (11) and inner medullary collecting duct cells $(8,12)$. However, the effect of increased osmolarity on cellular responses to ET has not been studied.

The current experiments tested the hypothesis that ET responsiveness is modulated by ambient osmolarity. Cultured renal medullary interstitial cells (RMICs) were studied since these cells normally reside in the renal medulla, and respond to ET by acting on the $\mathrm{ET}_{\mathrm{A}}$ receptor subtype to transiently increase intracellular calcium, prostaglandin release, and phosphotidylinositol hydrolysis (13). Ligand binding and Northern blot analysis were used to test the hypothesis that increased osmolarity modulates ET signaling in RMICs due to changes in the expression of specific surface receptors.

\section{Methods}

\section{Cell culture}

RMICs were used in all experiments. Previous work from several laboratories has established that these cells are a target for endothelin-1 action $(13-16)$. Cell cultures were maintained in a complete growth medium composed of RPMI 1640 supplemented with $10 \%$ heat-inactivated newborn calf serum to which $2.5 \mathrm{mg}$ insulin, $2.5 \mathrm{mg}$ transferrin, $2.5 \mu \mathrm{g}$ sodium selenite, $100 \mathrm{U} / \mathrm{ml}$ penicillin, and $50 \mu \mathrm{g} / \mathrm{ml}$ streptomycin were added. The osmolarity of the culture medium was verified to be 280 $300 \mathrm{mOsm} / \mathrm{kg} \mathrm{H}_{2} \mathrm{O}$ by the freezing point depression method utilizing a Micro-Osmometer (Advanced Instruments, Norwood, MA). Cells were grown either on sterile 25 -mm diam glass coverslips (microfluorometry), six-well culture dishes (prostaglandin determination), or $75-\mathrm{cm}^{2}$ plastic flasks (receptor binding). Cultures were maintained in a humidified incubator at $37^{\circ} \mathrm{C}$ in $95 \%$ air- $5 \% \mathrm{CO}_{2}$ (culture medium $\mathrm{pH} 7.3$ ) and fed at intervals of $48 \mathrm{~h}$. In selected experiments, hyperosmolarity of the medium was achieved by the addition of urea, sodium chloride plus urea, or mannitol, and verified by direct measurements. Cell viability was assessed by trypan blue exclusion with studies performed when 
viabilities were $>85 \%$. Endothelin-1 binding in cultured RMICs was stable through at least 80 passages; passages $18-74$ were studied in these experiments.

\section{Endothelin-1 radioreceptor measurements}

Tissue preparation. RMICs grown to confluence in $75-\mathrm{cm}^{2}$ flasks were harvested by the brief addition of trypsin-EDTA $(0.05 \%$ trypsin +0.53 mM EDTA $\cdot 4 \mathrm{Na}$ ) to the culture flask. Cells were pelleted, washed twice with Dulbecco's phosphate buffered saline (dPBS), and resuspended in sucrose buffer for homogenization (Polytron PTA 10S [Brinkman Instruments Inc., Westbury, NY], setting 7, $30 \mathrm{~s}$ ). The homogenate was centrifuged at $1000 \mathrm{~g}$ for $5 \mathrm{~min}\left(4^{\circ} \mathrm{C}\right)$, the resultant supernatant centrifuged at $44,000 \mathrm{~g}$ for $65 \mathrm{~min}$, and the resulting pellet resuspended in sucrose buffer and frozen at $-70^{\circ} \mathrm{C}$. On the day of the binding studies, the tissue was slowly thawed at room temperature. Protein content was determined by the method of Lowry using BSA as the standard (17).

Radioligand receptor binding assay. Binding studies were performed in a total volume of $250 \mu \mathrm{l}$ containing: plasma membranes ( 5 $\mu \mathrm{g}$ of membrane protein in $25 \mu \mathrm{l}$ of sucrose buffer), and $225 \mu \mathrm{l}$ of binding buffer comprised of the following (in $\mathrm{mM}$ ): 50 Tris, $154 \mathrm{NaCl}$, 1 EDTA, $25 \mathrm{MnCl}_{2}, 1 \mathrm{~N}$-acetyl-DL-methionine, and 2.5\% BSA (RIA grade), buffered to $\mathrm{pH}$ 7.5. The $N$-acetyl-DL-methionine was added to preserve the integrity of the sulfhydryl bridges in ET. Assay tubes were incubated at $25^{\circ} \mathrm{C}$ in a Dubnoff shaking water bath at 60 cycles/min with varying amounts of ET for $4 \mathrm{~h}$ as previously described (13). The binding reaction was interrupted by addition of $3 \mathrm{ml}$ of ice-cold TRISisosaline, $\mathrm{pH} 7.5$ ( $50 \mathrm{mM}$ TRIS in $0.154 \mathrm{M} \mathrm{NaCl})$ to the reaction tube, and bound counts separated from free by rapid filtration through glassfiber filters (no. 30; Schleicher \& Schuell, Keene, NH). The test tube and the trapped membrane fragments were washed with three 3-ml vol of ice-cold buffer. The filters were analyzed for ${ }^{125}$ I using a gamma radiation detector (LKB 1277; GammaMaster, Turku, Finland). ET (0.1 $\mu \mathrm{M}$ ) caused maximal displacement of the ligand and defined the level of nonspecific binding. Specific binding was determined as the difference between the amount of $\left[{ }^{125} \mathrm{I}\right]$-ET bound in the absence and presence of $0.1 \mu \mathrm{M}$ ET.

Equilibrium binding studies were performed at $25^{\circ} \mathrm{C}$. Eight concentrations of $\left.{ }^{125} \mathrm{I}\right]-\mathrm{ET}(4-500 \mathrm{pM})$ were studied in the presence and absence of $0.1 \mu \mathrm{M}$ unlabeled ET, yielding total and nonspecific binding isotherms. Specific binding, calculated as the difference between total and nonspecific binding, was analyzed using nonlinear regression curve fitting analysis of the untransformed data and by linear regression analysis according to Scatchard (18) to yield estimates of receptor density $\left(\mathrm{B}_{\max }\right)$ and apparent dissociation constants $\left(K_{\mathrm{d}}\right)$. In some experiments, the binding of a single concentration of $\left[{ }^{125} \mathrm{I}\right]$-ET $(25 \mathrm{pM})$ to RMIC membranes was examined in the presence and absence of unlabeled ET $(0.1 \mu \mathrm{M})$.

\section{Monitoring of changes in cytosolic free $\mathrm{Ca}^{2+}$ concentration}

Changes in cytosolic free $\mathrm{Ca}^{2+}$ concentration, $\left[\mathrm{Ca}^{2+}\right]_{\mathrm{i}}$, were monitored microfluorometrically using the $\mathrm{Ca}^{2+}$-sensitive indicator FURA-2AM as previously described $(13,19-21)$. Briefly, cells grown on $25-\mathrm{mm}$ diam glass coverslips were incubated with $5 \mu \mathrm{M}$ FURA-2AM in a humidified incubator at $37^{\circ} \mathrm{C}$ in $95 \%$ air-5\% $\mathrm{CO}_{2}(15-20 \mathrm{~min})$. Loaded monolayers were rinsed $(3 \times)$ and assayed in a buffer comprised of the following: $135 \mathrm{mM} \mathrm{NaCl}, 5 \mathrm{mM} \mathrm{KCl}, 1.5 \mathrm{mM} \mathrm{CaCl}_{2}, 1 \mathrm{mM} \mathrm{MgCl}$, $2 \mathrm{mM} \mathrm{NaH}_{2} \mathrm{PO}_{4}, 5 \mathrm{mM}$ glucose; and $5 \mathrm{mM} \mathrm{N}$-2-hydroxyethyl-piperazine- $N^{\prime}$-2-ethanesulfonic acid (Hepes) titrated to $\mathrm{pH} 7.4$ at $37^{\circ} \mathrm{C}$ and bubbled with oxygen. The final osmolarity of all solutions used was $300 \mathrm{mOsm} / \mathrm{kg} \mathrm{H}_{2} \mathrm{O}$. A Nikon Diaphot inverted microscope (Nikon Inc., Garden City, NY) equipped with a $40 \times$ CF fluor objective and coupled to a dual excitation spectrofluorometer system (PTI; Delta San, S. Brunswick, NJ), equipped with a chopper and operated via a desk top computer was employed. Excitation wavelengths were set at 340/380 $\mathrm{nm}$ (3-nm slit widths). A 400-nm dichroic mirror and 510-nm barrier filter allowed for collection of emitted light at the appropriate wave- length. Ratio $340 / 380$ was converted to $\left[\mathrm{Ca}^{2+}\right]_{\mathrm{i}}$ according to the formula described by Grynkiewicz et al. (19).

Figures presented are data from typical representative experiments or pooled data from at least three experiments as detailed in the individual figure legends.

\section{Prostaglandin $E_{2}$ determination}

Prostaglandin $\mathrm{E}_{2}\left(\mathrm{PGE}_{2}\right)$ production by RMICs was measured using a standard radioimmunoassay (22). Briefly, confluent monolayers grown in six-well culture dishes were washed with dPBS, and incubated for 3 $\mathrm{h}$ at $37^{\circ} \mathrm{C}$ in either isosmolar RPMI or in RPMI made hyperosmolar $\left(600 \mathrm{mOsm} / \mathrm{kg} \mathrm{H}_{2} \mathrm{O}\right)$ by addition of urea. To initiate an experiment, monolayers were placed in fresh media to which ET $\left(10^{-8} \mathrm{M}\right)$ or vehicle was added, and incubation proceeded at $37^{\circ} \mathrm{C}$ for $10 \mathrm{~min}$. Media was collected and frozen at $-20^{\circ} \mathrm{C}$ before quantitation of $\mathrm{PGE}_{2}$. Duplicate 50- $\mu \mathrm{l}$ aliquots were subjected to radioimmunoassay as previously described (22). All experiments were performed at least three times, each on a separate cell passage.

In preliminary studies, it was determined that exposure to hyperosmolarity for $3 \mathrm{~h}$ was without effect on basal $\mathrm{PGE}_{2}$ accumulation, but exposure for $24 \mathrm{~h}$ caused a 15 -fold stimulation. Therefore, the relationship between hyperosmolarity and ET-induced $\mathrm{PGE}_{2}$ accumulation was measured at $3 \mathrm{~h}$.

\section{Osmolar control of receptor transcription}

Total cellular RNA was extracted from cells by the acid guanidinium thiocyanate-phenol-chloroform method (RNAzol; Biotex Lab, Houston, TX) based on the method of Chomczynski and Sacchi (23). RNA (30 $\mu \mathrm{g})$ was fractionated on a formaldehyde $/ 1 \%$ agarose gel at $30 \mathrm{~V}$ for 16 $h$ and transferred to a nylon membrane (GIBCO BRL, Gaithersburg, MD). RNAs were immobilized on the membrane by baking in a vacuum oven for $2 \mathrm{~h}$ at $80^{\circ} \mathrm{C}$. The membrane was prehybridized in a solution

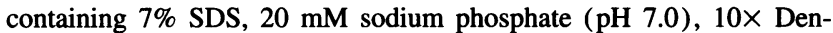
hardt's solution, $5 \times$ SSC buffer and $1 \mathrm{mg} / \mathrm{ml}$ Salmon Sperm DNA for $2 \mathrm{~h}$ at $65^{\circ} \mathrm{C}$. Hybridization proceeded for $16 \mathrm{~h}$ with an ET-specific oligomer, which was ${ }^{32} \mathrm{P}$ labeled by using T4 kinase (GIBCO BRL), in the same solution with $10 \%$ dextran added. After hybridization, the membrane was washed twice with $1 \times$ SSC buffer and $1 \%$ SDS at room temperature, one time at $50^{\circ} \mathrm{C}$, air dried, and autoradiographed with an intensifying screen for $24-72 \mathrm{~h}$ at $-80^{\circ} \mathrm{C}$. A synthetic oligonucleotide probe complementary to published sequences $(24,25)$ of rat $\mathrm{ET}_{\mathrm{A}}$ receptor subtype (5'TATCTCTCAGCATTGTCAGCGATTGCG 3') was synthesized at North Shore University Hospital with a DNA synthesizer (model 8700; MilliGen/Biosearch, Burlington, MA) using the $\beta$-cyanoethyl phosphoramidite chemistry. The oligonucleotide was purified by HPLC and 5' end-labeled with polynucleotide kinase and $\gamma-{ }^{32} \mathrm{P}$ ATP as described (26).

The blot was subsequently stripped by boiling in $1 \times$ SSC buffer for $5 \mathrm{~min}$ and reprobed with a $\beta$-actin cDNA fragment which was ${ }^{32} \mathrm{P}$ labeled using a commercial random priming kit (GIBCO BRL). The prehybridization solution contained $50 \%$ formamide, $5 \times$ SSCPE $(2.4$ $\mathrm{M} \mathrm{NaCl}, 0.3 \mathrm{M}$ sodium citrate, $0.2 \mathrm{M} \mathrm{KPO}_{4}, 0.02 \mathrm{M}$ EDTA), $5 \times$ Denhardt's solution and $500 \mu \mathrm{g} / \mathrm{ml}$ Salmon Sperm DNA. The hybridization solution contained $50 \%$ formamide, $5 \times$ SSCPE, $1 \times$ Denhardt's solution, $100 \mu \mathrm{g} / \mathrm{ml}$ Salmon Sperm DNA and 10\% dextran sulfate. After hybridization, the blot was washed thrice with $2 \times$ saline sodium citrate buffer, $0.1 \%$ SDS at $56^{\circ} \mathrm{C}$ for $15 \mathrm{~min}$ and then autoradiographed.

Three or four samples of RNA from $\sim 10^{8}$ cells from experimental and control groups were run on a single gel for comparison by densitometry. The autoradiographs were scanned with a laser densitometer (Ultroscan XL; LKB) and individual lanes were analyzed for the area in each peak using GelScan XL software on an IBM AT computer. The expression of mRNA for $\mathrm{ET}_{\mathrm{A}}$ receptor subtype was estimated as the ratio of the peak area for $\mathrm{ET}_{\mathrm{A}}$ divided by the peak area of $\beta$-actin which was used as a measure of total loaded RNA.

\section{Statistics}

Data are presented as the mean \pm standard error as the index of dispersion. All experiments were performed at least three times, each on a 
different cell passage. Where appropriate, analysis of variance and repeated measures ANOVA were applied using the SAS program on an IBM AT computer. The null hypothesis was rejected when the $P<0.05$.

\section{Materials}

The RPMI and penicillin-streptomycin solutions were purchased from GIBCO BRL and newborn calf serum from Sigma Immunochemicals (St. Louis, MO). Endothelin-1 (endothelin 1-21 [human, porcine]) was purchased from Peptide International (Louisville, KY). [ $\left.{ }^{125} \mathrm{I}\right]$-Endothelin-1 $(2,200 \mathrm{Ci} / \mathrm{mmol}),\left[{ }^{3} \mathrm{H}\right]-\mathrm{PGE}_{2}(200 \mathrm{Ci} / \mathrm{mmol}),\left[{ }^{3} \mathrm{H}\right]-\mathrm{SQ} 29548$ and $\left[{ }^{3} \mathrm{H}\right]$-dihydroalprenolol were obtained from Dupont-NEN (Boston, MA). All other vasoactive compounds used in the radioligand competition experiments were purchased from Sigma. FURA-2/AM was obtained from Molecular Probes (Eugene, OR) and EGTA from Fluka Chemical (Ronkonkoma, NY). AG1-x2 (100-200 mesh) formate anion exchange resin was purchased from Bio-Rad Labs. (Richmond, CA) and $\mathrm{PGE}_{2}$ anti-serum from Advanced Magnetics (Boston, MA). H-7 (1-[5-isoquinolinylsulfonyl]-2-methyl-piperazine) was purchased from Sigma. All standard chemicals used were purchased at the highest commercial grade available.

\section{Protocols}

The first protocol examined the effects of increased osmolarity on ET signaling in cells incubated in RPMI made hyperosmolar by the addition of urea $\left(600 \mathrm{mOsm} / \mathrm{kg} \mathrm{H}_{2} \mathrm{O}\right)$. Two signaling pathways were examined in response to ET $\left(10^{-8} \mathrm{M}\right)$ : agonist induced calcium transients and $\mathrm{PGE}_{2}$ accumulation.

The second protocol tested the effect of increasing osmolarity on the ET binding reaction. Cell membranes from RMICs grown under isosmotic conditions were incubated with $25 \mathrm{pM}$ of $\left[{ }^{125} \mathrm{I}\right]$-endothelin1 in Tris- $\mathrm{HCl}-\mathrm{MnCl}_{2}-\mathrm{BSA}$ buffer $\left(150 \mathrm{mOsm} / \mathrm{kg} \mathrm{H}_{2} \mathrm{O}\right)$ with the addition of urea to a final osmolarity of 300 or $600 \mathrm{mOsm} / \mathrm{kg} \mathrm{H}_{2} \mathrm{O}$.

The third protocol examined the relationship between various osmotic agents and ET receptor expression. The effects of hyperosmolarity ( $600 \mathrm{mOsm} / \mathrm{kg} \mathrm{H}_{2} \mathrm{O}, 24 \mathrm{~h}$ ) by urea alone, urea plus sodium chloride, and mannitol on ET receptor affinity and density were studied. The combination of urea plus $\mathrm{NaCl}$ was selected to mimic medullary osmolytes (10).

The fourth protocol examined the time course of changes in ET receptors by increased osmolarity (urea, $600 \mathrm{mOsm} / \mathrm{kg} \mathrm{H}_{2} \mathrm{O}$ ).

The fifth protocol studied the concentration dependence of increased osmolarity and changes in ET receptors in RMICs. RMICs were incubated with various amounts of urea to achieve osmolarities of 450,500 , 550,600 , and $750 \mathrm{mOsm} / \mathrm{kg} \mathrm{H}_{2} \mathrm{O}$. Membranes were isolated and the binding of $25 \mathrm{pM}$ of $\left[{ }^{125} \mathrm{I}\right]$-ET was measured.

The sixth protocol studied the specificity of the effects of hyperosmolarity on ET receptors by measuring an unrelated receptor, the $\beta$ adrenergic receptor. RMICs were incubated in isosmolar RPMI or hyperosmolar RPMI (urea, $600 \mathrm{mOsm} / \mathrm{kg} \mathrm{H}_{2} \mathrm{O}, 24 \mathrm{~h}$ ). Membranes were isolated and the binding of $25 \mathrm{pM}\left[{ }^{125} \mathrm{I}\right]-\mathrm{ET}$ or $\left.0.7 \mathrm{nM} \mathrm{[}{ }^{3} \mathrm{H}\right]$-dihydroalprenolol was measured. To determine whether the effects of hyperosmolarity can occur in cells that reside in the renal cortex and are not normally subject to wide variations in ambient osmolarity, we measured the binding of $25 \mathrm{pM}$ [ $\left.{ }^{125} \mathrm{I}\right]$-ET to freshly isolated membranes from glomerular mesangial cells (passages 11-18) exposed for $24 \mathrm{~h}$ to either isosmolar or hyperosmolar ( $600 \mathrm{mOsm} / \mathrm{kg} \mathrm{H}_{2} \mathrm{O}$ with urea) media.

The seventh protocol examined the role of protein kinase C (PKC). Since downregulation of many hormone receptors is mediated by PKC activation, we tested the effects of a PKC inhibitor, $\mathrm{H}-7$, on the changes in ET receptors induced by hyperosmolarity (urea, $600 \mathrm{mOsm} / \mathrm{kg} \mathrm{H}_{2} \mathrm{O}$, $24 \mathrm{~h}$ ). Confluent monolayers of RMICs were incubated in isosmotic or hyperosmotic RPMI in the absence and presence of H-7 $\left(10^{-6} \mathrm{M}\right)$ for $24 \mathrm{~h}$, and the binding of $25 \mathrm{pM}\left[{ }^{125} \mathrm{I}\right]-\mathrm{ET}$ to cell membranes was measured.

The eighth protocol examined the effects of hyperosmolarity (urea, $600 \mathrm{mOsm} / \mathrm{kg} \mathrm{H}_{2} \mathrm{O}, 24 \mathrm{~h}$ ) on the expression of mRNA for the $\mathrm{ET}_{\mathrm{A}}$ receptor subtype.

To test the potential role of protein synthesis on reduced endothelin-
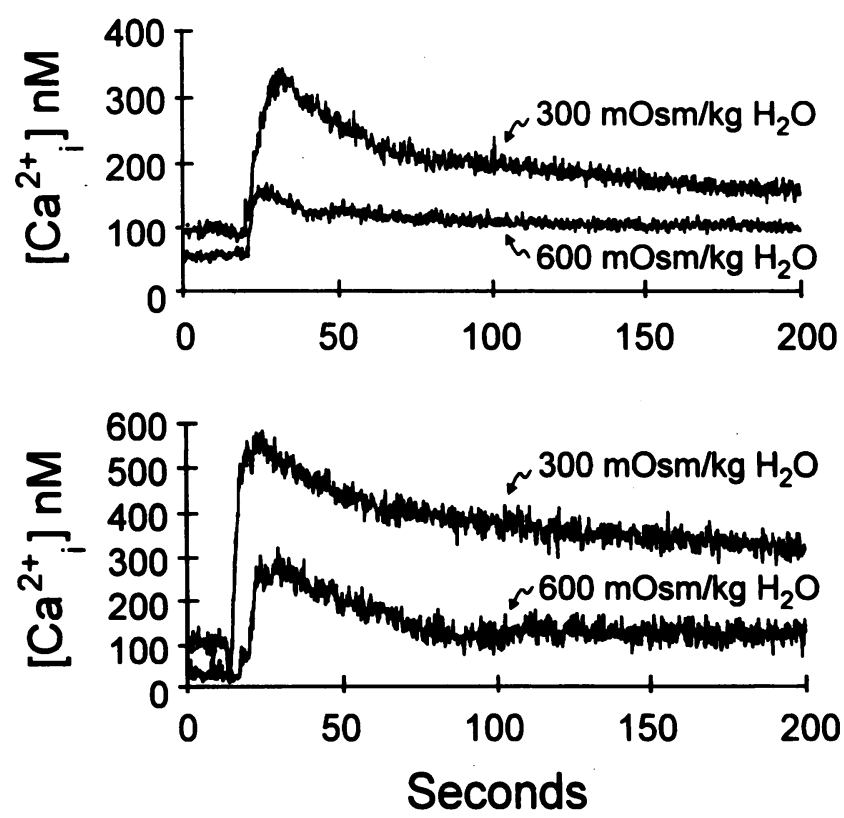

Figure 1. Effects of increased osmolarity on endothelin-induced intracellular calcium translocation in cultured rat RMICs. Confluent monolayers of cells were incubated for $3 \mathrm{~h}$ (top) or $24 \mathrm{~h}$ (bottom) in either isosmolar RPMI medium or in RPMI medium made hyperosmolar $(600 \mathrm{mOsm} /$ $\mathrm{kg} \mathrm{H}_{2} \mathrm{O}$ ) by the addition of urea. Cells were loaded with fura-2 and mounted onto the stage of a Nikon Diaphot microscope as detailed under Methods. Endothelin-1-elicited $\left(10^{-8} \mathrm{M}\right)$ intracellular $\mathrm{Ca}^{2+}$ mobilization was blunted in cells incubated in hyperosmolar medium compared with cells incubated in isosmolar medium. The results were virtually identical when cells were exposed to increased osmolarity for either 3 or $24 \mathrm{~h}$. Each tracing is a representative study.

1 receptor expression by hyperosmolarity, the ninth protocol studied the effects of protein synthesis inhibition on endothelin receptor expression. Cultured RMICs in isosmotic medium were preincubated with or without cycloheximide ( $25 \mu \mathrm{g} / \mathrm{ml}$ ) for $30 \mathrm{~min}$ at $37^{\circ} \mathrm{C}$. The dose of cycloheximide was selected on the basis of published studies demonstrating that at the dose used cycloheximide inhibited the incorporation of $\left[{ }^{3} \mathrm{H}\right]$ leucine by $50 \%$ (27). At the end of the preincubation, the osmolarity of the medium was either kept at $300 \mathrm{mOsm} / \mathrm{kg} \mathrm{H}_{2} \mathrm{O}$ or was increased to $600 \mathrm{mOsm} / \mathrm{kg} \mathrm{H} \mathrm{H}_{2} \mathrm{O}$ by the addition of urea. Endothelin receptors were measured at $24 \mathrm{~h}$.

\section{Results}

Effects of increased culture medium osmolarity on $\mathrm{Ca}^{2+}$ signaling and $P G E_{2}$ production. A representative tracing of the effect of increased culture medium osmolarity on ET-induced $\left[\mathrm{Ca}^{2+}\right]_{i}$ signaling in cultured RMICs is depicted in Fig. 1 . At $3 \mathrm{~h}$ exposure to ET $\left(10^{-8} \mathrm{M}\right)$, the ET-elicited $\left[\mathrm{Ca}^{2+}\right]_{i}$ increment was blunted in cells incubated in hyperosmolar medium (600 $\mathrm{mOsm} / \mathrm{kg} \mathrm{H}_{2} \mathrm{O}$ by the addition of urea) compared to cells incubated in isosmolar medium (Fig. 1, top). Almost identical results were obtained when cells were exposed to the hyperosmotic medium for $24 \mathrm{~h}$ (Fig. 1, bottom). A summary of the data obtained in 4-6 experiments is shown in Fig. 2. Under steady state conditions, intracellular calcium in the isosmolar and hyperosmolar groups was similar $(C)$. In contrast, the peak of the ET-evoked calcium transients was decreased by $58 \%$ in cells incubated in the hyperosmolar medium for $3 \mathrm{~h}(439 \pm 88$ vs. $186 \pm 38 \mathrm{nM} ; P<0.02$ ) (Fig. 2 , top) and decreased by $45 \%$ 

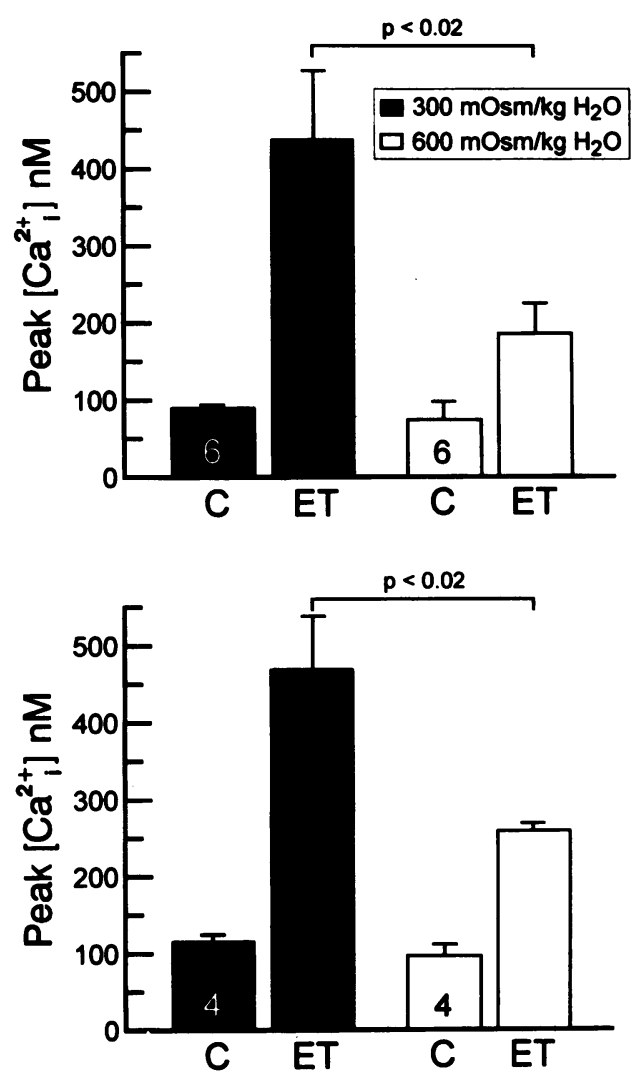

Figure 2. Effects of increased osmolarity on peak endothelin-induced intracellular calcium translocation in cultured rat RMICs. Confluent monolayers of cells were incubated overnight in either isosmolar RPMI medium or in RPMI medium made hyperosmolar $\left(600 \mathrm{mOsm} / \mathrm{kg} \mathrm{H}_{2} \mathrm{O}\right.$ ) by the addition of urea as described in Fig. 1. Unstimulated intracellular calcium was similar in the isosmolar and hyperosmolar groups $(C)$, but peak endothelin $\left(10^{-8} \mathrm{M}\right)$ responses were decreased by 58 and $45 \%$ in the cells incubated in hyperosmolar medium at $3 \mathrm{~h}$ (top) and $24 \mathrm{~h}$ (bottom), respectively. The numbers in the bars indicate the number of individual experiments.

in the cells incubated in hyperosmolar medium at $24 \mathrm{~h}(470 \pm 67$ vs. $260 \pm 9 \mathrm{nM} ; P<0.02$ ) (bottom).

In parallel experiments, the effect of hyperosmolarity (urea) on $\mathrm{PGE}_{2}$ accumulation was examined (Fig. 3). ET-stimulated $\mathrm{PGE}_{2}$ production was increased 16-fold in RMICs incubated under isosmolar conditions versus a twofold increment in cells incubated in hyperosmolar medium $(P<0.005)$. This observation was valid when the data were expressed as $\mathrm{pg} / 100 \mu \mathrm{l}$ of medium (top) or $\mathrm{pg} / 10^{6}$ cells (bottom).

Effects of increased osmolarity on endothelin receptor binding in vitro. Confluent monolayers of RMICs were grown under isosmotic conditions. Membranes prepared from these cells were incubated with $25 \mathrm{pM}$ of [ $\left.{ }^{125} \mathrm{I}\right]-\mathrm{ET}$ in either isosmolar ( $300 \mathrm{mOsm} / \mathrm{kg} \mathrm{H} \mathrm{H}_{2} \mathrm{O}$ ) or hyperosmolar assay binding buffer (urea, $600 \mathrm{mOsm} / \mathrm{kg} \mathrm{H}_{2} \mathrm{O}$ ). There was no effect of hyperosmolarity on endothelin binding (Table I). These data indicate that binding in vitro is not affected by increased osmolarity under the conditions of our experiment.

Effects of increased culture medium osmolarity on endothelin receptor density. ET receptor density was examined in cells exposed to $600 \mathrm{mOsm} / \mathrm{kg} \mathrm{H}_{2} \mathrm{O}$ with urea for $24 \mathrm{~h}$. A representative Scatchard plot is shown in Fig. 4. There was a
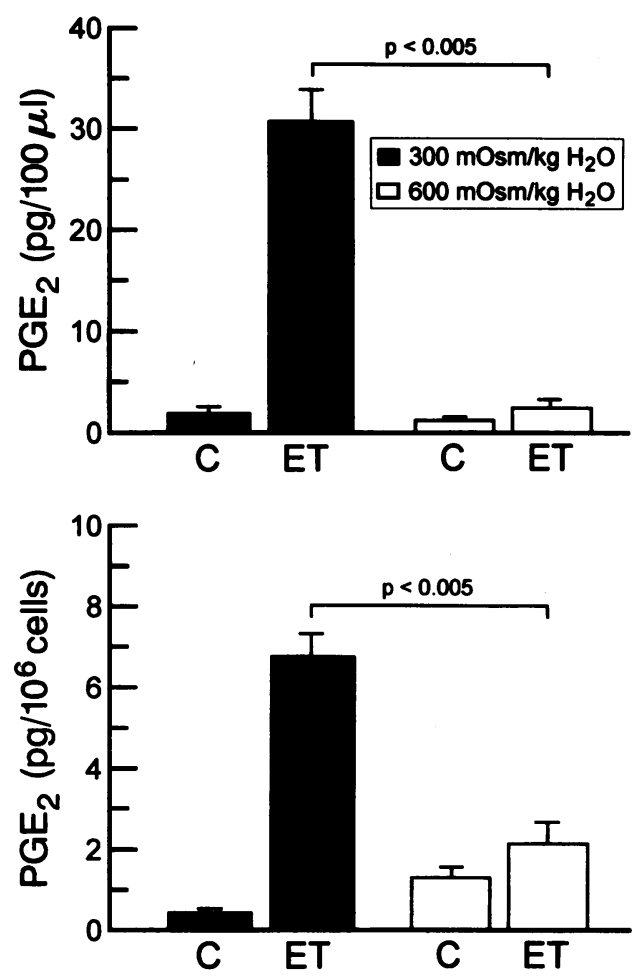

Figure 3. Effects of increased osmolarity on endothelin-induced prostaglandin $\mathrm{E}_{2}$ production in cultured rat RMICs. Confluent monolayers of cells were incubated for $3 \mathrm{~h}$ in either isosmolar RPMI medium or in RPMI medium made hyperosmolar $\left(600 \mathrm{mOsm} / \mathrm{kg} \mathrm{H}_{2} \mathrm{O}\right)$ by the addition of urea. At the beginning of the experiment the cells were placed in fresh media in the absence or presence of endothelin $\left(10^{-8} \mathrm{M}\right)$ and incubated at $37^{\circ} \mathrm{C}$ for $10 \mathrm{~min}$. Prostaglandin $\mathrm{E}_{2}$ was quantitated by radioimmunoassay. Data are presented as concentration of prostaglandin $\mathrm{E}_{2}(\mathrm{pg} / 100 \mu \mathrm{l})($ top $)$ or prostaglandin $\mathrm{E}_{2}$ per $10^{6}$ cells (bottom). Each bar is the mean of duplicate measurements performed in three individual experiments.

striking reduction in the number of ET receptor sites in the cells incubated under hyperosmolar conditions versus isosmolar conditions as indicated by a leftward shift in the $\mathrm{x}$-intercept. The equilibrium dissociation constants $\left(K_{\mathrm{d}}\right)$ were not different between the two groups as shown by the parallel slopes. The values for $\mathrm{B}_{\max }$ and $K_{\mathrm{d}}$ are shown in Fig. 5. The number of specific ET receptors in RMICs fell by $84 \%$ ( $1450 \pm 184$ vs. $238 \pm 12 \mathrm{fmol} / \mathrm{mg} ; P<0.01)$ after $24 \mathrm{~h}$ of incubation at 600 $\mathrm{mOsm} / \mathrm{kg} \mathrm{H}_{2} \mathrm{O}$. Increased osmolarity with urea was without

Table I. Effects of Increased Osmolarity on the Endothelin Binding Reaction In Vitro

\begin{tabular}{cc}
\hline Group & Specific ET bound \\
\hline & fmol/mg \\
$300 \mathrm{mOsm} / \mathrm{kg} \mathrm{H}_{2} \mathrm{O}(6)$ & $108 \pm 19$ \\
$600 \mathrm{mOsm} / \mathrm{kg} \mathrm{H}_{2} \mathrm{O} \mathrm{(6)}$ & $116 \pm 19$
\end{tabular}

RMICs were grown under isosmotic conditions. Membranes prepared from these cells were incubated with $25 \mathrm{pM}$ of $\left[{ }^{125} \mathrm{I}\right]$-endothelin- 1 in isosmotic $\left(300 \mathrm{mOsm} / \mathrm{kg} \mathrm{H} \mathrm{H}_{2} \mathrm{O}\right)$ or hyperosmolar $\left(600 \mathrm{mOsm} / \mathrm{kg} \mathrm{H}_{2} \mathrm{O}\right.$ by the addition of urea) binding assay buffer. 


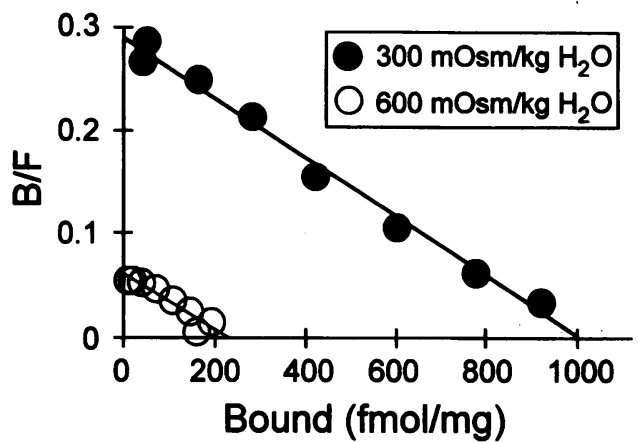

Figure 4. Representative Scatchard plot of endothelin binding ( ${ }^{125} \mathrm{I}-\mathrm{ET}$ ) in RMIC membranes prepared from cells incubated for $24 \mathrm{~h}$ at 300 $\mathrm{mOsm} / \mathrm{kg} \mathrm{H} \mathrm{H}_{2} \mathrm{O}$ or $600 \mathrm{mOsm} / \mathrm{kg} \mathrm{H}_{2} \mathrm{O}$. Endothelin binding sites were measured at equilibrium $(4 \mathrm{~h})$ at $25^{\circ} \mathrm{C}$ in membranes prepared from renal medullary interstitial cells grown in isosmolar medium ( 300 $\left.\mathrm{mOsm} / \mathrm{kg} \mathrm{H}_{2} \mathrm{O}\right)$ or hyperosmolar medium $\left(600 \mathrm{mOsm} / \mathrm{kg} \mathrm{H}_{2} \mathrm{O}\right)$. Specific binding was calculated as the difference between total and nonspecific binding. Points are means of triplicate measurements in a representative experiment. $B$, specific bound endothelin- $1 ; F$, unbound endothelin-1.
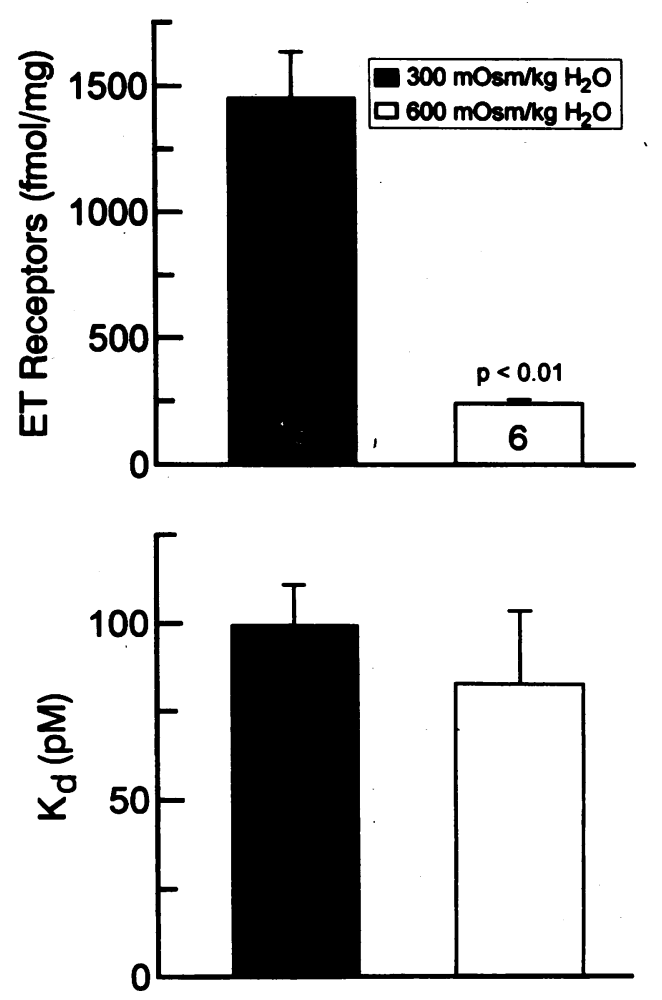

Figure 5. Effects of hyperosmolarity on endothelin receptor sites in RMICs. Renal medullary interstitial cells grown to confluence were incubated in isosmolar medium $\left(300 \mathrm{mOsm} / \mathrm{kg} \mathrm{H}_{2} \mathrm{O}\right)$ or in medium made hyperosmolar $\left(600 \mathrm{mOsm} / \mathrm{kg} \mathrm{H}_{2} \mathrm{O}\right)$ by the addition of urea. At $24 \mathrm{~h}$, cells exposed to hyperosmolar conditions had a $84 \%$ reduction in the number of specific endothelin receptor sites using Scatchard analyses $(t o p)$, whereas receptor affinity $\left(K_{d}\right)$ was unchanged (bottom). The numbers in the bars indicate the number of experiments.

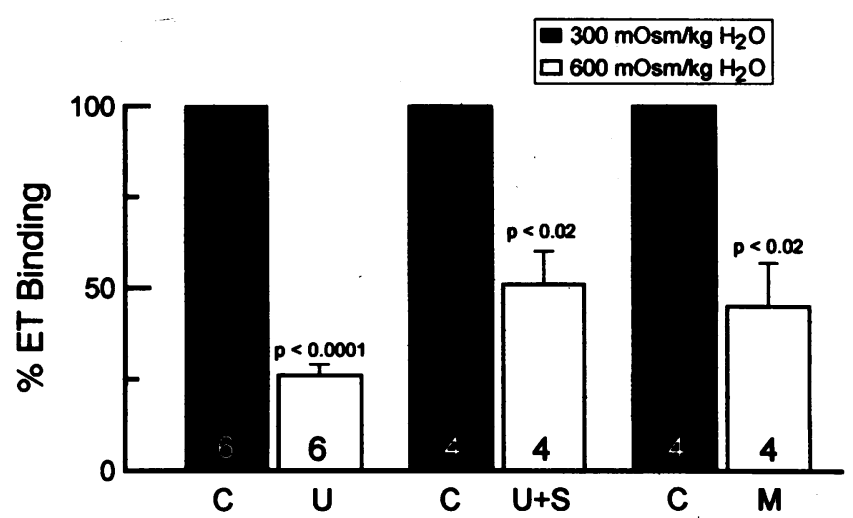

Figure 6. Effects of hyperosmolarity induced by urea, mannitol, or urea plus sodium chloride on endothelin receptor sites in RMICs. RMICs grown to confluence were incubated in isosmolar medium $(C)$, or in media made hyperosmolar to $600 \mathrm{mOsm} / \mathrm{kg} \mathrm{H}_{2} \mathrm{O}$ by the addition of urea alone $(U)$, mannitol $(M)$, or urea plus sodium chloride $(150 \mathrm{mOsm}$ urea plus $150 \mathrm{mOsm} \mathrm{NaCl})(U+S)$ for $24 \mathrm{~h}$. Endothelin binding sites were measured at equilibrium $(4 \mathrm{~h})$ at $25^{\circ} \mathrm{C}$ in prepared RMIC membranes. Results are reported as the percent binding compared with controls. Each experiment was performed in triplicate. The numbers in the bars indicate the number of individual experiments.

effect on $K_{\mathrm{d}}$ (control vs. hyperosmolar, $99 \pm 12$ vs. $83 \pm 21 \mathrm{pM}$; $P=$ NS) .

The specificity of the effects of hyperosmolarity on the density of ET receptors in RMICs was examined by comparing cells incubated at $600 \mathrm{mOsm} / \mathrm{kg} \mathrm{H}_{2} \mathrm{O}$ with either urea alone, urea plus $\mathrm{NaCl}$, or mannitol. In all the experimental groups the number of receptors was reduced by at least $51 \%$ (Fig. 6). Therefore, the fall in ET receptor density by hyperosmolarity was independent of the osmotic agent used.

To test whether the effects of osmolarity on ET receptors was specific for RMICs, we studied the effects of increasing osmolarity with urea on ET receptor expression in glomerular mesangial cells. The binding of $25 \mathrm{pM}$ [ $\left.{ }^{125} \mathrm{I}\right]-\mathrm{ET}$ to mesangial cells was reduced from an isosmolar control of $21.8 \pm 5.9$ to $16.0 \pm 4.8 \mathrm{fmol} / \mathrm{mg}(29.1 \pm 9.6 \%$ reduction, $P<0.05)$.

Additional experiments were performed to determine the time course and concentration dependence of changes in ET receptors in response to hyperosmolarity. $20 \mathrm{~min}$ after challenge with hyperosmolar medium (urea, $600 \mathrm{mOsm} / \mathrm{kg} \mathrm{H}_{2} \mathrm{O}$ ) the binding of $25 \mathrm{pM}\left[{ }^{125} \mathrm{I}\right]$-endothelin-1 to RMIC membranes was not changed $(-2.0 \pm 4.7 \%, N=7, P=\mathrm{NS})$. However, three hours following the establishment of a hyperosmolar stimulus with urea $\left(600 \mathrm{mOsm} / \mathrm{kg} \mathrm{H} \mathrm{H}_{2} \mathrm{O}\right)$, the number of specific ET receptor sites (Scatchard analysis) was reduced from a control level of $1450 \pm 184 \mathrm{fmol} / \mathrm{mg}$ to $532 \pm 82 \mathrm{fmol} / \mathrm{mg}(P<0.05)$ (Fig. 7). At $24 \mathrm{~h}$, the receptor number was further reduced to $238 \pm 12 \mathrm{fmol} / \mathrm{mg}(P<0.01$ vs. isosmolar controls; $P<0.01$ vs. $3 \mathrm{~h}$ group).

The effect of incremental changes in osmolarity with urea on the specific binding of ET was measured at $24 \mathrm{~h}$. Increases in osmolarity from $450-750 \mathrm{mOsm} / \mathrm{kg} \mathrm{H}_{2} \mathrm{O}$ caused a doserelated reduction in specific ET binding whether expressed in fmol/mg (Fig. 8, top) or percent change from control values (Fig. 8, bottom). This dose-related decrease reached statistical significance when compared to the isosmolar control at hyperosmolar stimuli above $500 \mathrm{mOsm} / \mathrm{kg} \mathrm{H}_{2} \mathrm{O}$. These results indicate 


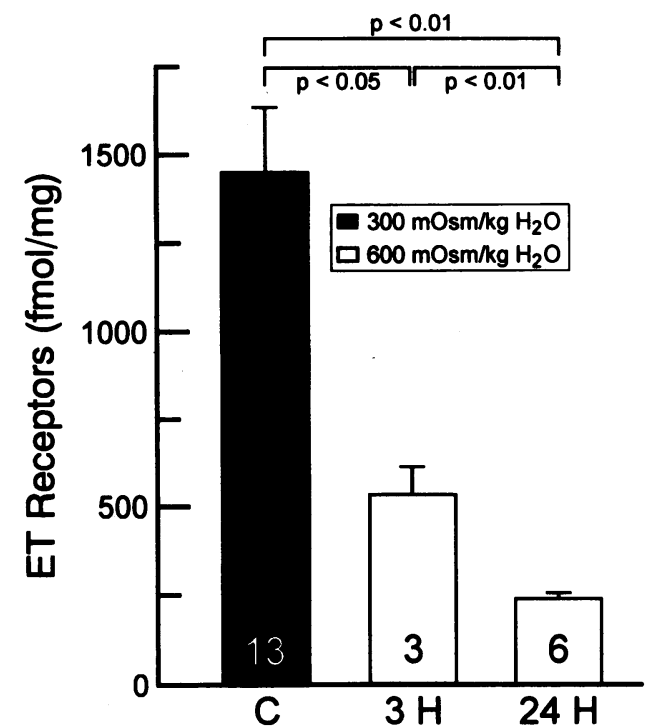

Figure 7. Time course of hyperosmolar-induced reductions in endothelin receptor sites. RMICs were grown to confluence in either isosmolar RPMI medium, or RPMI medium made hyperosmolar by the addition of urea $\left(600 \mathrm{mOsm} / \mathrm{kg} \mathrm{H}_{2} \mathrm{O}\right)$ for either 3 or $24 \mathrm{~h}$. Endothelin binding sites were measured at equilibrium $(4 \mathrm{~h})$ at $25^{\circ} \mathrm{C}$ in prepared RMIC membranes. Specific binding was calculated as the difference between total and nonspecific binding. The number of specific endothelin receptor sites was reduced at 3 and $24 \mathrm{~h}$. The numbers in the bars indicate the number of individual experiments.

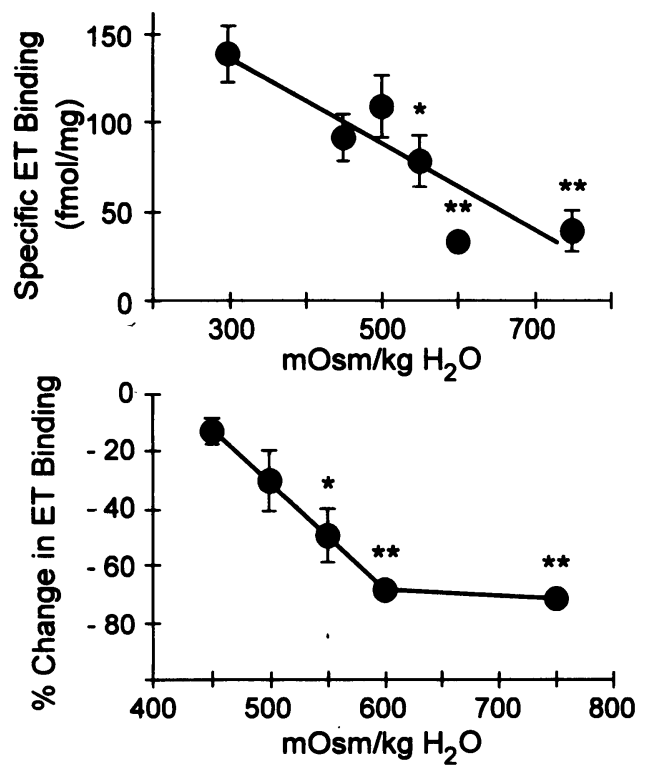

Figure 8. Dose-response of the effects of hyperosmolarity on specific endothelin binding in RMICs. RMICs grown to confluence were incubated in isosmolar medium $\left(300 \mathrm{mOsm} / \mathrm{kg} \mathrm{H}_{2} \mathrm{O}\right)$, or in media made hyperosmolar by the addition of various concentrations of urea to achieve osmolarities indicated on the abscissa. Specific binding of 25 pM of [ $\left.{ }^{125} \mathrm{I}\right]$-endothelin-1 was measured on membranes prepared from cells exposed to various osmolarities for $24 \mathrm{~h}$. $* P<0.05 \mathrm{vs.} 300 \mathrm{mOsm} /$ $\mathrm{kg} \mathrm{H}_{2} \mathrm{O} ; * * P<0.01$ vs. $300 \mathrm{mOsm} / \mathrm{kg} \mathrm{H}_{2} \mathrm{O}$. Each point represents a minimum of four individual experiments. Note that the scales of the abscissa are different in the upper and lower panels.
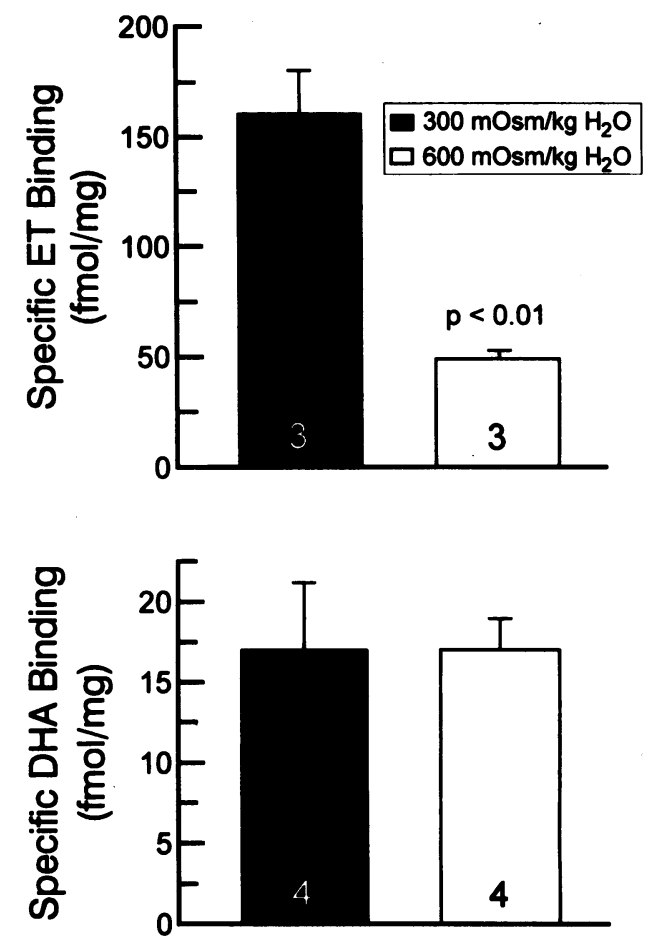

Figure 9. Effects of hyperosmolarity on endothelin and dihydroalprenolol receptor sites in RMICs. RMICs grown to confluence were incubated in isosmolar medium ( $300 \mathrm{mOsm} / \mathrm{kg} \mathrm{H}_{2} \mathrm{O}$ ), or in media made hyperosmolar $\left(600 \mathrm{mOsm} / \mathrm{kg} \mathrm{H}_{2} \mathrm{O}\right)$ by the addition of urea. Specific binding of $25 \mathrm{pM}$ of [ $\left.{ }^{125} \mathrm{I}\right]$-endothelin- 1 or $0.7 \mathrm{nM}$ of [ $\left.{ }^{3} \mathrm{H}\right]$-dihydroalprenolol were measured on membranes prepared from cells incubated for $24 \mathrm{~h}$ Hyperosmolarity $\left(600 \mathrm{mOsm} / \mathrm{kg} \mathrm{H}_{2} \mathrm{O}\right)$ caused a decrease in specific endothelin binding $(P<0.01)$ but did not have an effect on dihydroalprenolol binding $(P=\mathrm{NS})$. Each experiment was performed with triplicate measurements. The numbers in the bars indicate the number of experiments.

that ET binding is decreased by hyperosmolarity in a dosedependent manner and may require an "osmolar threshold."

To determine whether the reduction in receptor number induced by hyperosmolarity was specific for ET or part of a more generalized effect, the effect of hyperosmolarity with urea on the binding of dihydroalprenolol, a nonselective $\beta$-adrenergic receptor antagonist, was studied. Specific binding of ET or dihydroalprenolol was measured on membranes prepared from cells incubated for $24 \mathrm{~h}$ in isosmolar or hyperosmolar $(600 \mathrm{mOsm} /$ $\mathrm{kg} \mathrm{H}_{2} \mathrm{O}$ ) media. Hyperosmolarity decreased specific ET binding by $70 \%(161 \pm 19 \mathrm{fmol} / \mathrm{mg}$, isosmolar group vs. $49 \pm 3 \mathrm{fmol} /$ $\mathrm{mg}$, hyperosmolar group; $P<0.01$ ), but was without effect on dihydroalprenolol binding ( $17 \pm 4 \mathrm{fmol} / \mathrm{mg}$, isosmolar group vs. $17 \pm 2 \mathrm{fmol} / \mathrm{mg}$, hyperosmolar group; $P=\mathrm{NS}$ ) (Fig. 9). Angiotensin II and thromboxane binding were also explored, but no specific binding on RMIC membranes was detected.

Potential role of protein kinase $C$ in endothelin receptor signaling. The potential role of PKC in down-regulating ET receptors under conditions of hyperosmolarity was studied using the PKC inhibitor, H-7 (Fig. 10). H-7 was without effect on ET binding $(108 \pm 15 \%)$ in cells grown at $300 \mathrm{mOsm} / \mathrm{kg} \mathrm{H}_{2} \mathrm{O}$. When cells were exposed to hyperosmolarity with urea (600 $\mathrm{mOsm} / \mathrm{kg} \mathrm{H}_{2} \mathrm{O}$ ) for $24 \mathrm{~h}$, there was a $69 \pm 7 \%$ reduction in the ET binding $(P<0.01)$. H-7 did not mitigate the reduction in ET binding under hyperosmolar conditions $(66 \pm 9 \%$ reduction, 


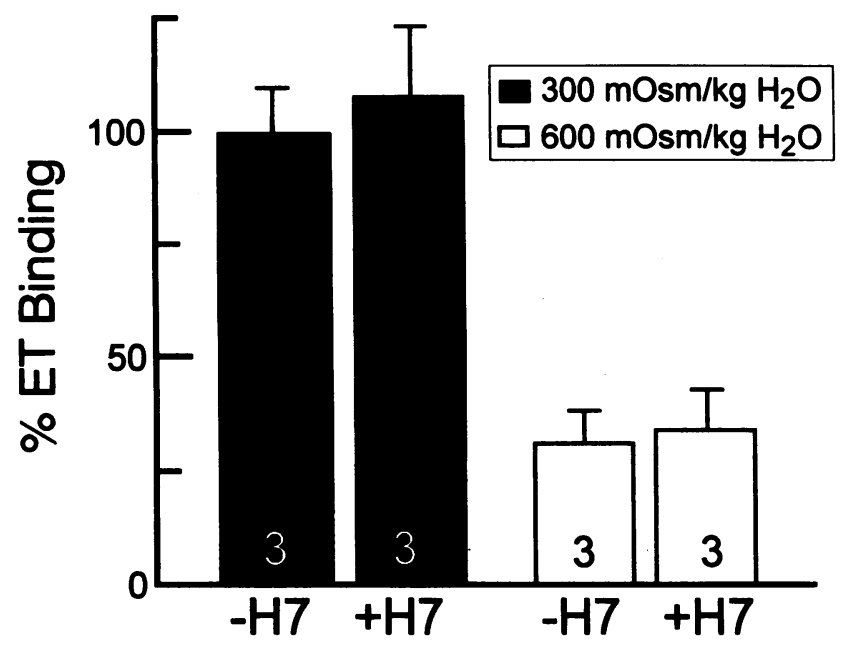

Figure 10. Effects of protein kinase $\mathrm{C}$ inhibition on the reduction in specific endothelin binding induced by hyperosmolarity. RMICs were grown to confluence in RPMI medium. On the day of the experiment cells were exposed to fresh RPMI medium ( $300 \mathrm{mOsm} / \mathrm{kg} \mathrm{H}_{2} \mathrm{O}$ ) or RPMI medium made hyperosmolar by the addition of urea $(600 \mathrm{mOsm} /$ $\mathrm{kg} \mathrm{H}_{2} \mathrm{O}$ ) for $24 \mathrm{~h}$ in the presence or absence of the protein kinase $\mathrm{C}$ inhibitor, $\mathrm{H} 7\left(10^{-6} \mathrm{M}\right)$. Specific endothelin-1 binding was measured at the dose below the dissociation constant, $K_{d}(25 \mathrm{pmol})$ as detailed in Methods. Each experiment was performed in triplicate and the numbers in the bars indicate the number of individual experiments.

$P=$ NS vs. hyperosmolarity alone). The $K_{\mathrm{d}}$ also was not affected by $\mathrm{H}-7$.

Evaluation of the role of hyperosmolarity on endothelin receptor $m R N A$. To determine whether hyperosmolarity reduced ET receptor expression at the transcriptional level, Northern blot analysis was performed using an $\mathrm{ET}_{\mathrm{A}}$ receptor specific cDNA oligomer. As illustrated in Fig. 11, $\mathrm{ET}_{\mathrm{A}}$ receptor subtype mRNA was significantly increased by exposure of monolayers to hyperosmolar culture medium $(P<0.05)$.

Effects of protein synthesis inhibition on hyperosmolarityinduced down-regulation of endothelin receptors. The effects of protein synthesis inhibition on hyperosmolarity-induced downregulation of endothelin receptors was studied by measuring the binding of $25 \mathrm{pM}\left[{ }^{125} \mathrm{I}\right]$-endothelin 1 in the presence and absence of cycloheximide (Fig. 12). Increasing osmolarity to 600 $\mathrm{mOsm} / \mathrm{kg} \mathrm{H}_{2} \mathrm{O}$ with urea reduced endothelin binding by $68.2 \pm 9.1 \%(N=5, P<0.01)$. Protein synthesis inhibition with cycloheximide in the absence of a hyperosmolar challenge reduced endothelin binding by $65.4 \pm 7.8 \%(N=5, P<0.01)$. When RMICs pretreated with cycloheximide were challenged with hyperosmolarity, endothelin binding was reduced by $80.6 \pm 4.2 \%(N=5, P<0.01$ vs. control; $P=$ NS vs. cycloheximide or urea groups).

\section{Discussion}

These experiments tested the hypothesis that responsiveness of RMICs to ET is modulated by changes in ambient osmolarity. The peak calcium transient in response to ET was blunted by $45-58 \%$ in cells exposed to the hyperosmolar medium, and $\mathrm{PGE}_{2}$ production was significantly blunted. These findings raised the question of abnormal receptor expression. An 84\% reduction in ET receptor density was observed in cells cultured

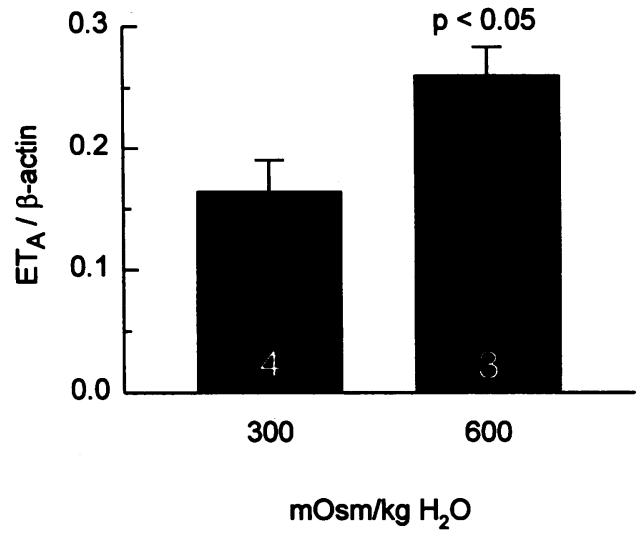

Figure 11. Effects of hyperosmolarity on the expression of endothelin1 receptor subtype A mRNA. mRNA was isolated from confluent RMICs exposed to either isosmolar medium, or medium made hyperosmolar by the addition of urea to achieve a final osmolarity of $600 \mathrm{mOsm}$ $\mathrm{kg} \mathrm{H}_{2} \mathrm{O}$ for $24 \mathrm{~h}$. Northern analysis on a single gel with comparison by densitometry indicated that the message for the $\mathrm{ET}_{\mathrm{A}}$ receptor subtype was increased by a hyperosmolar stimulus of $600 \mathrm{mOsm} / \mathrm{kg} \mathrm{H}_{2} \mathrm{O}$ at 24 $\mathrm{h}(P<0.05)$ when expressed as ET $/ \beta$-actin. The expression of mRNA for $\mathrm{ET}_{\mathrm{A}}$ receptor subtype was estimated as the ratio of the peak area for $\mathrm{ET}_{\mathrm{A}}$ divided by the peak area of $\beta$-actin which was used as a measure of total loaded RNA. Each experiment was repeated three or four times using mRNA isolated from individual flasks containing $\sim 10^{8}$ cells.

in hyperosmolar medium compared with cells grown under isosmolar conditions while $K_{\mathrm{d}}$ was unaffected. The reduction in ET binding was not specific for a single osmotic agent since similar reductions occurred when the osmolarity of the culture media was increased by the addition of urea, urea plus sodium chloride or mannitol. However, the effect of increased osmolarity on receptor number was specific for ET receptors since hyperosmolarity was without effect on the binding of the unrelated ligand, dihydroalprenolol. Whereas the effects of hyperosmolarity on cell function are likely to be most pronounced in the renal

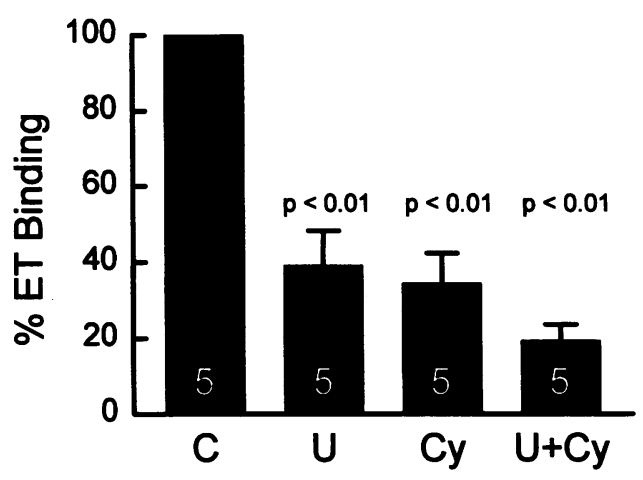

Figure 12. Effects of protein synthesis inhibition on endothelin-1 receptor expression. RMICs were incubated for $30 \mathrm{~min}$ at $37^{\circ} \mathrm{C}$ in the presence or absence of cycloheximide $(25 \mu \mathrm{g} / 100 \mathrm{ml})$ and incubations continued for $24 \mathrm{~h}$ in the presence or absence of a hyperosmolar challenge by the addition of urea to the media (final osmolarity $600 \mathrm{mOsm} / \mathrm{kg} \mathrm{H} \mathrm{H}_{2} \mathrm{O}$ ). The specific binding of $25 \mathrm{pM}$ of [ $\left.{ }^{125} \mathrm{I}\right]$-endothelin-1 was compared in membranes isolated from the RMICs. $C$, control (no cycloheximide, medium $300 \mathrm{mOsm} / \mathrm{kg} \mathrm{H}_{2} \mathrm{O} ; U$, urea; $C y$, cycloheximide; $U+C y$, urea plus cycloheximide. $P$ values represent differences from $C$. There were no differences between $\mathrm{U}, \mathrm{Cy}$, or $\mathrm{U}+\mathrm{Cy}$ groups. 
medulla where osmolarities exceeding $1200 \mathrm{mOsm} / \mathrm{kg} \mathrm{H}_{2} \mathrm{O}$ are found in states of water deprivation, our studies demonstrate that cells that reside outside the renal medulla (i.e., glomerular mesangial cells) can also downregulate the expression of ET receptors when challenged by hyperosmolarity. However, the ET receptor downregulation by hyperosmolarity was less pronounced in glomerular mesangial cells than in RMICs.

The role of medullary osmolarity on modulating the production of ET peptide by inner medullary collecting duct cells has been previously investigated. ET production was decreased when the media was made hyperosmolar with mannitol (8). Urea either had no effect (8) or inhibited (12) ET production. The effect of hyperosmolarity induced by sodium on ET production was reported by one group to be reduced (8), and by another group to be stimulated (12). The reasons for these discrepant findings is not immediately apparent, but it appears that changes in the osmolarity bathing inner medullary collecting duct cells can clearly modify ET production. The action of ET is dependent on both the amount produced and the ability of cells to respond. In the present study, we demonstrate that increases in osmolarity induced by either impermeable or freely permeable osmolytes significantly reduced the expression of ET receptors in cultured RMICs.

The mechanism whereby hyperosmolarity might modulate ET receptor expression was further explored. One possible mechanism could be homologous down-regulation by increased local production of the ET peptide. This is unlikely since RMICs have not been shown to produce ET in vivo (28) or in vitro (Wilkes, unpublished observations). Also, homologous downregulation of receptors generally occurs within $20 \mathrm{~min}$ and is associated with reduced, not increased, expression of receptor mRNA (29). ET receptors did not down-regulate when challenged with hyperosmolarity for $20 \mathrm{~min}$. A second mechanism may involve induction of PKC which, in turn, can mediate down-regulation of ET receptors (30-33). This is also unlikely since H-7, a PKC inhibitor, was without effect on the reduction in ET receptors following incubation with $600 \mathrm{mOsm} / \mathrm{kg}$ urea.

Endothelin receptor expression may also be regulated at the level of transcription. Previous experiments in our laboratories have demonstrated that RMICs express the $\mathrm{ET}_{\mathrm{A}}$, but not $\mathrm{ET}_{\mathrm{B}}$ receptor subtype (13). Therefore, to test this hypothesis, mRNA was isolated from confluent RMICs exposed to either isosmolar or hyperosmolar medium. Northern analysis indicated that the message for the $\mathrm{ET}_{\mathrm{A}}$ receptor subtype was increased by the hyperosmolar stimulus. These data support the conclusion that the reduction in the number of ET receptors was not a result of homologous downregulation. Thus, ET receptor down-regulation by hyperosmolarity in the face of a significant increase in receptor mRNA expression strongly suggests a posttranscriptional mechanism.

An additional experiment was performed to test the hypothesis that osmolarity regulated ET receptor expression at the level of protein synthesis. When RMICs were incubated with the protein synthesis inhibitor cycloheximide for $24 \mathrm{~h}$, there was a greater than $65 \%$ reduction in ET binding which was similar to the reduction in ET binding that occurred in RMICs challenged with hyperosmolarity alone or protein synthesis inhibition plus hyperosmolarity. These data raise the interesting possibility that the mechanism by which hyperosmolarity reduces the ET receptor expression is by inhibiting the production of new receptors to replace receptors being internalized or degraded. ET receptors may normally act as a feedback inhibitor of transcription of its own mRNA, which may explain why $\mathrm{ET}_{\mathrm{A}}$ receptor mRNA was increased by hyperosmolarity. This new hypothesis and other possible explanations need to be studied.

Further insights into the mechanisms underlying reduced ET receptor expression may be found in studies pertaining to other ligand-receptor systems. Ambient osmolarity may have profound effects on hormone signaling pathways in a variety of cell types by fundamental changes in the cellular production, distribution, configuration and function of receptors. Osmolarity has been implicated in the modulation of the function of two distinct receptors in polymorphonuclear (PMN) leukocytes (34) and hepatocytes (35). In PMN leukocytes, hyperosmolar medium inhibited receptor-mediated uptake of the chemotactic peptide, $N$-formylnorleucyl-leucylphenylalanine. The inhibition was independent of the solute used to increase osmolarity $(\mathrm{NaCl}$, sucrose or lactose) and had little effect on saturable peptide binding. However, it did prevent clustering of surface molecules as indicated by the inhibition of capping of fluorescent concanavalin A. Interestingly, hyperosmolar medium prevented the peptide-stimulated increase in intracellular calcium concentration which paralleled the inhibition of receptor-mediated uptake. Hyperosmolarity reduced the rate of endocytosis without affecting the number of saturable receptor sites. A similar finding was observed by Oka et al. (35) who studied galactosyl receptor-mediated uptake in isolated rat hepatocytes. In contrast with these findings, our studies demonstrated that hyperosmolarity reduces both the number of specific ET receptors and receptor signaling in RMICs.

Changes in renal medullary osmolarity, ET receptor activity and the renal response to dehydration are likely to be closely linked. Whereas increased interstitial fluid osmolarity generally leads to cell dysfunction due to intracellular dehydration, increased osmolarity of the renal medulla and its local effects on cell function may be essential for maximally preserving fluid and electrolyte balance during states of severe water deprivation. The ways in which cells of the renal medulla adapt to hyperosmolar stress are not well understood, but the mechanism appears to involve changes in the way cells respond to hormones and autacoids (36). The current study demonstrates that the response of RMICs to ET is blunted in hyperosmolar states. Since RMICs are a rich source of $\mathrm{PGE}_{2}$ which is released in response to ET (13), it is possible that blunting of the ET response may impede $\mathrm{PGE}_{2}$ production that may be required to maintain renal blood flow. Reductions of renal blood flow in hyperosmolar states favor maximal water reabsorption by preventing washout of the medullary hyperosmolarity needed to maximally conserve water. Other adaptive mechanisms induced by hyperosmolarity contribute to body fluid homeostasis during hyperosmolar stress. For example, hyperosmolarity has been shown to increase the cAMP response to antidiuretic hormone in inner medullary collecting duct cells that favors water reabsorption by the distal nephron segments (36).

In summary, this study demonstrates osmolar regulation of ET receptor expression and signaling by renal medullary interstitial cells. Since ET acts in the renal medulla to induce a water diuresis, we hypothesize that the blunting of ET action during states of volume depletion (high medullary osmolarity) may favor the conservation of water and restoration of volume status. The current observations provide yet another mechanism by which increased osmolarity may regulate the ET autacrine system in the renal medulla. 


\section{Acknowledgments}

This work was supported in part by PHS grants HL40914 and HL44373 (B. M. Wilkes), GM45919 (M.-d. Y. Chang), DK36351 (E. P. Nord) and by grants from the American Heart Association, New York State Affiliate (M. A. Vernace) and National (M.-d. Y. Chang), and Long Island Heart Council (M. A. Vernace). M. A. Vernace was the recipient of a fellowship award from the National Kidney Foundation of New York/New Jersey, Inc. The microspectrofluorometer was purchased in part with matching funds obtained from a challenge grant from the Research Foundation of the State University of New York at Stony Brook (E. P. Nord).

\section{References}

1. Yanagisawa, M., H. Kurihara, S. Kimura, Y. Tomobe, M. Kobayashi, Y. Mitsui, Y. Yazaki, K. Goto, and T. Masaki. 1988. A novel potent vasoconstrictor peptide produced by vascular endothelial cells. Nature (Lond.). 332:411-415.

2. Kohan, D. E. 1991. Endothelin synthesis by rabbit renal tubule cells. Am. J. Physiol. 261:F221-F226.

3. Wilkes, B. M., M. Susin, P. F. Mento, C. M. Macica, E. P. Girardi, E. Boss, and E. P. Nord. 1991. Localization of endothelin-like immunoreactivity in rat kidneys. Am. J. Physiol. 260:F913-F920.

4. King, A. J., B. M. Brenner, and S. Anderson. 1989. Endothelin: a potent renal and systemic vasoconstrictor peptide. Am. J. Physiol. 256:F1051-F1058.

5. Denton, K. M., and W. P. Anderson. 1990. Vascular actions of endothelin in the rabbit kidney. Clin. Exp. Pharmacol. Physiol. 17:861-872.

6. Schnermann, J., J. N. Lorenz, J. P. Briggs, and J. A. Keiser. 1992. Induction

of water diuresis by endothelin in rats. Am. J. Physiol. 263:F516-F526.

7. Zeidel, M. L., H. R. Brady, B. C. Kone, S. R. Gullans, and B. M. Brenner. 1989. Endothelin, a peptide inhibitor of $\mathrm{Na}^{+}-\mathrm{K}^{+}$-ATPase in intact renal tubular epithelial cells. Am. J. Physiol. 257:C1101-C1107.

8. Kohan, D. E., and E. Padilla. 1993. Osmolar regulation of endothelin-1 production by rat inner medullary collecting duct. J. Clin. Invest. 91:1235-1240.

9. Nadler, S. P., J. A. Zimpelmann, and R. L. Hebert. 1992. Endothelin inhibits vasopressin-stimulated water permeability in rat terminal inner medullary collecting duct. J. Clin. Invest. 90:1458-1466.

10. Garcia-Perez, A., and M. B. Burg. 1991. Renal medullary organic osmolytes. Physiol. Rev. 71:1081-1115.

11. Schramek, H., G. Gstraunthaler, C. C. Willinger, and W. Pfaller. 1993. Hyperosmolality regulates endothelin release by Madin-Darby canine kidney cells. J. Am. Soc. Nephrol. 4:206-213.

12. Yang, T., Y. Terada, H. Nonoguchi, K. Ujiie, K. Tomita, and F. Marumo. 1993. Effect of hyperosmolality on production and mRNA expression of.ET-1 in inner medullary collecting duct. Am. J. Physiol. 264:F684-F689.

13. Wilkes, B. M. A. S. Ruston, P. F. Mento, E. P. Girardi, D. Hart, M Vander Molan, R. Barnett, and E. P. Nord. 1991. Characterization of endothelin 1 receptor and signal transduction mechanisms in rat medullary interstitial cells. Am. J. Physiol. 260:F579-F589.

14. Barnett, R. L., L. Ruffini, D. Hart, P. Mancuso, and E. P. Nord. 1994 Mechanism of endothelin activation of phospholipase $A_{2}$ in rat renal medullary interstitial cells. Am. J. Physiol. 266:F46-F56.

15. Fontoura, B. M. A., D. R. Nussenzveig, K. M. Pelton, and T. Maack 1990. Atrial natriuretic factor receptors in cultured renomedullary interstitial cells. Am. J. Physiol. 258:C692-C699.

16. Muirhead, E. E., G. Germain, B. E. Leach, J. A. Pitcock, P. Stephenson,
B. Brooks, W. L. Brosius, E. G. Daniels, and J. G. Hinman. 1972. Production of renomedullary prostaglandins by renomedullary interstitial cells grown in tissue culture. Circ. Res. (Suppl). 31:161-172.

17. Lowry, O. H., N. J. Rosebrough, A. L. Farr, and R. J. Randall. 1951. Protein measurement with the Folin phenol reagent. J. Biol. Chem. 193:265-275.

18. Scatchard, G. 1949. The attractions of proteins for small molecules and ions. Ann. NY Acad. Sci. 51:660-672.

19. Grynkiewicz, G., M. Poenie, and R. Y. Tsien. 1985. A new generation of $\mathrm{Ca}^{2+}$ indicators with greatly improved fluorescence properties. J. Biol. Chem. 260:3440-3450.

20. Aboolian, A., and E. P. Nord. 1988. Bradykinin increases cytosolic free $\left[\mathrm{Ca}^{2+}\right]$ in proximal tubule cells. Am. J. Physiol. 255:F486-F493.

21. Aboolian, A., M. Vander Molen, and E. P. Nord. 1989. Differential effects of phorbol esters on $\mathrm{PGE}_{2}$ and bradykinin-induced elevation of $\left[\mathrm{Ca}^{2+}\right]_{\mathrm{i}}$ in $\mathrm{MDCK}$ cells. Am. J. Physiol. 256:F1135-F1143.

22. Barnett, R., P. A. Ortiz, S. Blaufox, S. Singer, E. P. Nord, and L. Ramsammy. 1990. Atrial natriuretic factor alters phospholipid metabolism in mesangial cells. Am. J. Physiol. 258:C37-C45.

23. Chomczynski, P., and N. Sacchi. 1987. Single-step method of RNA isolation by acid guanidinium thiocyanate-phenol-chloroform extraction. Anal. Biochem. 162:156-159.

24. Arai, H., S. Hori, I. Aramori, H. Ohkubo, and S. Nakanishi. 1990. Cloning and expression of a cDNA encoding an endothelin receptor. Nature (Lond.). 348:730-732.

25. Sakurai, T., M. Yanagisawa, Y. Takuwa, H. Miyazaki, S. Kimura, K. Goto, and T. Masaki. 1990. Cloning of a cDNA encoding a non-isopeptideselective subtype of the endothelin receptor. Nature (Lond.). 348:732-735.

26. Sambrook, J., E. F. Fritsch, and T. Maniatis. 1989. Molecular Cloning:

A Laboratory Manual. Plainview, N.Y., Cold Spring Harbor Laboratory Press.

27. Ullian, M. E., and S. Linas. 1989. Role of receptor cycling in the regulation

of angiotensin II surface receptor number and angiotensin II uptake in rate vascular smooth muscle cells. J. Clin. Invest. 84:840-846.

28. Nunez, D. J. R., M. J. Brown, A. P. Davenport, C. B. Neylon, J. P. Schofield, and R. K. Wyse. 1990. Endothelin-1 mRNA is widely expressed in porcine and human tissues. J. Clin. Invest. 85:1537-1541.

29. Sakurai, T., H. Morimoto, Y. Kasuya, Y. Takuwa, H. Nakauchi, T. Masaki, and $\mathrm{K}$. Goto. 1992. Level of $\mathrm{ET}_{\mathrm{B}}$ receptor mRNA is down-regulated by endothelins through decreasing the intracellular stability of mRNA molecules. Biochem. Biophys. Res. Commun. 186:342-347.

30. Cozza, E. N., M. C. Vila, and C. E. Gomez-Sanchez. 1990. ET-1 receptors in C6 cells: homologous downregulation and modulation by protein kinase C. Mol. Cell. Endocrinol. 70:155-164.

31. Mironneau, C., L. Rakotoarisoa, I. Sayet, and J. Mironneau. 1991. Modulation of $\left[{ }^{3} \mathrm{H}\right]$ dihydropyridine binding by activation of protein kinase $\mathrm{C}$ in vascular smooth muscle. Eur. J. Pharmacol. 208:223-230.

32. Awazu, M., R. E. Parker, B. R. Harvie, I. Ichikawa, and V. Kon. 1991. Down-regulation of endothelin-1 receptors by protein kinase $\mathbf{C}$ in streptozotocin diabetic rats. J. Cardiovasc. Pharmacol. (Suppl.) 17:S500-S502.

33. Pachter, J. A. R. Mayer-Ezell, R. M. Cleven, and A. B. Fawzi. 1993 Endothelin $\left(\mathrm{ET}_{\mathrm{A}}\right)$ receptor number and calcium signalling are up-regulated by protein kinase C- $\beta 1$ overexpression. Biochem. J. 294:153-158.

34. Daukas, G., and S. H. Zigmond. 1985. Inhibition of receptor-mediated but not fluid-phase endocytosis in polymorphonuclear leukocytes. J. Cell Biol. 101:1673-1679.

35. Oka, J. A., M. D. Christensen, and P. H. Weigel. 1989. Hyperosmolarity inhibits galactosyl receptor-mediated but not fluid phase endocytosis in isolated rat hepatocytes. J. Biol. Chem. 264:12016-12024.

36. Ishikawa, S., T. Saito, and T. Kusuya. 1985. Role of osmolarity in an antagonism of prostaglandin E on vasopressin-induced cellular cAMP in the cultured renal papillary collecting tubule cells. Biomed. Res. 6:269-274. 